\title{
Nara Leão: entre a bossa nova e a canção engajada
}

\author{
[ Nara Leão: between bossa nova and protest song
}

\section{Ismael de Oliveira Gerolamox}

Agradeço à Coordenação de Aperfeiçoamento de Pessoal de Nível Superior - Capes pelo auxílio financeiro e pela bolsa concedida (processo n. BEX 6905/15-3) para a realização de estágio de doutorado na Universitat Autònoma de Barcelona (Espanha).

RESUMO - Nara Leão foi uma das principais intérpretes da canção brasileira. Sua singular trajetória artística teve início nos anos I960, período de grande efervescência cultural e política, quando atuou como intérprete de diferentes repertórios de canção popular - da bossa nova à tropicália - e em espetáculos cênico-musicais. Partindo do pressuposto de que sua produção é uma das chaves para a compreensão dos debates e transformações da canção popular no período, discutiremos aqui os primeiros anos de sua carreira e o seu primeiro disco. Buscaremos verificar o modo pelo qual tais debates em torno da música popular, em grande medida conectados a discussões culturais e políticas mais amplas, se expressam no trabalho da cantora. PALAVRAS-CHAVE .
Nara Leão; bossa nova; arte engajada; música popular brasileira. · ABSTRACT - Nara Leão was one of the main singers of Brazilian popular music. Her career began in the I960's, a cultural and political turbulent period, when she worked as a singer of different musical repertoires - from bossa nova to tropicália - and as an actress in scenic-musical shows. Assuming that her work is essential to understanding debates and transformations of Brazilian popular music, we discuss the early years of her career and his first album. We will try to verify the way such questions about popular music, largely connected to cultural and political discussions, are expressed in the singer's work. · KEYWORDS · Nara Leão; bossa nova; engaged art; Brazilian popular music.

Recebido em I4 de março de 2016

Aprovado em I4 de outubro de 2016

GEROLAMO, Ismael de Oliveira. Nara Leão: entre a bossa nova e a canção engajada. Revista do Instituto de Estudos Brasileiros, Brasil, n. 66, p. I72-I98, abr. 2017.

DOI: http://dx.doi.org/10.11606/issn.2316-901X.vo166p172-198

I Universidade Estadual de Campinas (Unicamp, Campinas, SP, Brasil). 
Figura de destaque do cenário cultural dos anos de I960, Nara Leão desempenhou importante papel como intérprete de canções populares e eventualmente como atriz. A cantora iniciou sua trajetória junto aos músicos ligados à bossa nova, tornando-se, inclusive, uma das principais figuras femininas desse estilo musical. Posteriormente, ocupou a linha de frente daquilo que se pode nomear como "canção engajada" (em um período em que atuou como atriz nos espetáculos Opinião e Liberdade, liberdade), bem como aderiu à tropicália no final da década. Na medida em que sua trajetória se confunde com o próprio desenvolvimento da canção popular do período, sua produção discográfica traduz de modo exemplar as transformações e debates que marcaram esse sistema artístico. Funcionando, pois, como "síntese das questões em jogo nos anos 60"2, parece pertinente deter-se na análise dessa produção, em que pese sua "riqueza de repertório e tratamento"3, bem como sua importância para a demarcação de um novo cenário musical no país4.

Seguindo tais proposições, o presente trabalho busca descrever os primeiros anos de atuação da intérprete e analisar, musical e esteticamente, seu primeiro long-play (LP) - com destaque para aspectos como "sonoridade", arranjos e performance vocal - de modo a lançar luz sobre as transformações da canção popular aí manifestas que estiveram sintonizadas com debates mais amplos do cenário cultural do período, quais sejam: a perspectiva do engajamento político, a "modernização" ou "sofisticação" do cancioneiro popular e a busca das "raízes" culturais populares.

Para tanto, no que se refere aos referenciais teóricos e aos métodos utilizados, de maneira a reconstituir brevemente certos aspectos da trajetória da intérprete, serviram como fonte materiais publicados em jornais, revistas e livros, bem como, para a análise e descrição de aspectos de sua produção discográfica, recorreu-se a determinadas ferramentas analíticas e noções críticas presentes na literatura voltada à música popular.

É de interesse aqui, sobretudo, pensar a trajetória de Nara Leão como um

2 NAPOLITANO, Marcos. Seguindo a canção: engajamento político e indústria cultural na MPB (I959-I969). São Paulo: Annablume/Fapesp, 200I, p. I36.

3 Ibidem.

4 NAVES, Santuza. Canção popular no Brasil. Rio de Janeiro: Civilização Brasileira, 20Io, p. 55. 
microprocesso inserido num plano mais amplo de transformações e debates ${ }^{5}$, no sentido de que as escolhas e os posicionamentos da intérprete, ainda que vistos como decisões individuais, podem ser mais bem compreendidos se considerados os aspectos de um processo mais amplo, no plano social, em que tais ações ocorrem e que acabam por definir suas consequências ${ }^{6}$. Donde se tem o escopo do presente trabalho: investigar, a partir de tais perspectivas, as primeiras produções da cantora - os anos iniciais de sua carreira, seu disco de estreia, assim como suas tomadas de posição, escolhas e declarações no período.

\section{Do apartamento ao palco, Nara e OS PRimeiros anOS DE bOSSA}

Figuram na história da música brasileira popular, como importantes locais onde se ensaiou e engendrou o fenômeno bossa nova, alguns redutos específicos da cidade do Rio de Janeiro. Em um desses, localizado na Avenida Atlântica, residia Nara Leão. Em fins dos anos I950, enquanto se dedicava ao estudo do violão ${ }^{7}$, a adolescente Nara convivia em sua residência com alguns dos músicos considerados responsáveis pelo advento do novo estilo musical. Carlos Lyra, Roberto Menescal, Ronaldo Bôscoli,

5 Em certa medida, esse aporte metodológico se aproxima daquilo que se nomeou micro-história, donde o foco numa experiência individual acaba por propiciar a discussão de questões mais amplas do contexto sócio-histórico envolvido. GUINZBURG, Carlo. O queijo e os vermes. São Paulo: Cia. Das letras, 2006. Vale salientar que os esforços aqui não pretendem necessariamente a produção de uma biografia histórica, uma vez que a aproximação a esse aporte micro-historiográfico corresponde a uma operação profícua para pensar a relação de uma trajetória específica em relação ao contexto no qual se insere. Ou seja, a partir da redução na escala de observação - que pode também permitir a revelação de certos detalhes pouco explicitados e, por vezes, ignorados - focalizando um personagem específico de determinado contexto, pretende-se também lançar luz sobre questões mais amplas que estavam em jogo no período investigado. Também, a intenção aqui não se restringe à produção de uma biografia musical de Nara Leão, mas à compreensão de certo desenvolvimento da canção popular através do estudo de uma trajetória, tomando, portanto, o particular como ponto de partida e buscando identificar seu significado à luz de seu próprio contexto. LEVI, Giovanni. Sobre a micro-história. In: BURKE, P. (Org.). A escrita da história: novas perspectivas. São Paulo: Editora da Unesp, I992.

6 ELIAS, Norbert. Mozart: sociologia de um gênio. Rio de Janeiro: Jorge Zahar, I994. Ademais, é importante salientar que, a partir de aspectos relativos à produção da intérprete, não se pretende realizar qualquer tipo de generalização mecânica em relação ao contexto cultural do período. Daí que os apontamentos mais amplos dados a partir desse enfoque reduzido poderiam somente elucidar determinado corte da realidade sócio-histórica e ajudar-nos a compreender sua complexidade. O particular continua sendo o particular, ainda que ele possa nos auxiliar a compreender a complexidade do "todo".

7 Nara, a partir de I954, então com I2 anos, estudou violão com Patrício Teixeira - cantor e violonista da "velha guarda" que participou de gravações e apresentações ao lado de nomes importantes, como Pixinguinha -, posteriormente, foi aluna de Solon Ayala, violonista concertista ("clássico"), graças ao incentivo de seu pai, Jairo Leão. Ver: CABRAL, Sérgio. Nara Leão: uma biografia. Rio de Janeiro: Lumiar, 200I, p. I8-I9; NARA LEÃO. Site oficial. Cronologia. Disponível em: 〈http://www.naraleao.com.br/index.php?p=cronologia $>$. Acesso em: 27 maio 2015 . 
Luís Carlos Vinhas, Normando Santos e Chico Feitosa eram alguns dos assíduos frequentadores dessas reuniões musicais. Com o tempo, somaram-se a eles Oscar Castro Neves, Baden Powell, Luis Eça, Bebeto, Dori Caymmi, entre outros, como o já experiente cantor Lúcio Alves e Sylvinha Telles, cantora em início de carreira. Ainda que com menor frequência, Tom Jobim e Vinícius de Moraes, artistas que já eram referência para Nara e seus colegas, assim como João Gilberto, também marcavam presença em alguns desses encontros ${ }^{8}$.

É difícil definir com clareza o nível de protagonismo da jovem Nara Leão nessas reuniões musicais. Declarações a posteriori dos atores envolvidos não raro apresentam controvérsias sobre esse período. Para o biógrafo da cantora, Sérgio Cabral, ela "ocupava uma posição especial no grupo, naturalmente por ser a dona da casa e ainda por tocar muito bem violão, pela boa memória (decorava facilmente boa parte das canções que compunham o repertório do grupo) e pelas manifestações críticas sempre oportunas". Ademais, Roberto Menescal teria dito ao biógrafo que Nara tinha uma mentalidade mais avançada que seus pares, daí sua "posição especial”. De maneira oposta, a própria intérprete, ao recordar esse período de sua vida em depoimento ao Museu da Imagem e do Som - MIS (Rio de Janeiro), afirmou que não contava com o reconhecimento da maioria de seus colegas: "é... porque eu me sentia sem talento. E, depois, eles não me davam muita colher de chá não, eles me maltratavam muito, achavam que eu cantava mal, que eu desafinava - 'Cala a boca!' - Todo mundo me maltratava, eu ficava assim meio perdida” ${ }^{\text {o. }}$. Para Ronaldo Bôscoli, namorado da jovem à época, os atributos da cantora realmente não agradavam muito: "eu era muito rigoroso em relação a ela. Não gostava do jeito dela cantar, não dava a menor força. Nos festivais que eu promovia, ela nunca era a estrela. Ficava sempre num segundo plano - eu realmente não via nela nenhuma possibilidade de êxito"זr. Ainda segundo o letrista e produtor, o próprio João Gilberto teria dito que a cantora possuía limitações: "É, a Nara canta, mas ela semitona um pouco"ז

Fato é que, cantando bem ou "semitonando", em primeiro ou segundo plano, a presença de Nara foi uma constante nos vários shows de bossa nova realizados no final da década de I950. Entre os anos de I958 e I959, os jovens músicos frequentadores do apartamento de Nara deram início a essas apresentações. A primeira delas ocorreu na Faculdade de Arquitetura da Universidade do Brasil, na Praia Vermelha, na cidade do Rio de Janeiro. Convidados pelo diretório acadêmico, Nara, Menescal e seus parceiros realizaram uma "samba session" no teatro de arena da referida instituição. Segundo Menescal, a apresentação teve grande êxito junto ao público.

8 CABRAL, Sergio, op. cit., p. 32-33.

9 Ibidem.

Io LEÃO, Nara. Depoimento. Museu da Imagem e do Som - MIS. Rio de Janeiro, 6 jul. I977. (Depoimento de Nara Leão a João Vicente Salgueiro, Roberto Menescal e Sérgio Cabral). In: GOMES, A. A. de A. (Org.). Nara Leão - Encontros. Rio de Janeiro: Azougue Editorial, 20I4, p. 25.

II BÔSCOLI, Ronaldo. Eles e eu: memórias de Ronaldo Bôscoli. Depoimento a L. C. Maciel e A. Chaves. Rio de Janeiro: Nova Fronteira, I994, p. I70-I7I.

I2 Ibidem. 
A segunda apresentação foi realizada no Grupo Universitário Hebraico do Brasil, a convite do jovem jornalista Moisés Fuks, também frequentador do apartamento de Nara Leão. Ronaldo Bôscoli, o mais velho entre os músicos, que não raro fazia o papel de porta-voz e organizador do grupo, convidou Sylvinha Telles para ser a atração principal do show, uma vez que a cantora já havia participado de algumas gravações e apresentações profissionais e poderia contribuir para atrair maior número de ouvintes. Conta-se que os cartazes para divulgação da apresentação continham a seguinte mensagem: "Sylvia Telles e um grupo bossa nova”. Fuks teria empregado o termo bossa nova por não saber como denominar o conjunto de músicos participantes do show - possivelmente, essa foi uma das primeiras vezes em que se utilizou o termo bossa nova para designar o estilo musical desses jovens. Após tais aparições, o grupo apresentou, em setembro de I959, o Iํㅜ Festival de Samba-Session, novamente na Faculdade de Arquitetura, e, em novembro do mesmo ano, na Escola Naval, o show intitulado Segundo comando da operação bossa nova. Além dessas, foram muitas as apresentações em locais privados - casas e apartamentos de artistas e figuras públicas, clubes da alta sociedade etc. - realizadas pelos jovens músicos.

É certo que Nara Leão esteve presente em praticamente todas essas primeiras aparições dos jovens bossa-novistas. Contudo, segundo seu biógrafo, sua estreia como cantora teria ocorrido somente no show realizado na Escola Naval, onde interpretou as canções "Fim de noite", de Ronaldo Bôscoli e Chico Feitosa, e "Se é tarde me perdoa”, de Carlos Lyra e Ronaldo Bôscoli ${ }^{\mathrm{x}}$. Contudo, para Roberto Menescal, a primeira aparição em público da cantora foi aquela do teatro de arena da Faculdade de Arquitetura - a "samba session" de I958. Nara teria estreado interpretando a referida canção de Lyra e Bôscoli ${ }^{14}$. A própria cantora não tinha tanta certeza sobre a versão de Menescal: "Eu não sei. Eu cantei, agora, eu não sei se eu queria cantar ou se eu não queria, se me botaram no palco porque estava faltando alguém para cantar. Foi meio embrulhado assim”.5. Nos meses seguintes, as apresentações tornaram-se cada vez mais constantes, assim como a presença de Nara no palco, ainda que não ocupasse posição de destaque. Marco da ascensão da bossa nova foi o show intitulado Noite do amor, do sorriso e da flor, realizado novamente na Faculdade de Arquitetura, em maio de I960. Para Menescal, esse teria sido o espetáculo em que os próprios músicos empenharam-se em lançar oficialmente o "movimento" bossa-novista ${ }^{\mathrm{I}}$. Em reportagem publicada no Última hora (Rio de Janeiro), no dia 23, lê-se: "O próximo espetáculo terá que ser mesmo no Maracanãzinho. O movimento está crescendo e a data de 20 de maio será sempre lembrada como o dia do autêntico festival da 'bossa nova”.' A reportagem também exaltou a participação de João Gilberto, nomeado como “o papa bossa-nova”, e a estreia de sua esposa Astrud Gilberto ${ }^{\mathrm{T}}$.

I3 CABRAL, Sérgio, op. cit., p. 44-45; NARA LEÃO. Site oficial, op. cit.

I4 MENESCAL, Roberto apud LEÃO, Nara, 20I4, op. cit., p. 25-26.

I5 LEÃO, Nara, 20I4, op. cit., p. 26.

I6 Ibidem, p. 27.

I7 “BOSSA NOVA" foi à faculdade: ganhou nota Io!. Última hora, Rio de Janeiro, 23 de maio de I96o. Caderno 2, p. Io. 
Paralelamente às primeiras apresentações dos músicos bossa-novistas no circuito universitário, tomavam forma, nos estúdios da gravadora Odeon, as colaborações entre Tom Jobim e João Gilberto. Em julho de I958, iniciaram-se as gravações que compuseram o 78 rotações de João Gilberto e, posteriormente, o LP Chega de saudade, lançado em I959.

\section{BOSSA NOVA, A SÍNTESE MODERNA}

O lançamento de Chega de saudade é considerado um marco, um “divisor de águas”, na história da música popular. São muitos os estudos e opiniões críticas que apontam os elementos musicais aí presentes como sendo de importância central para uma "mudança de paradigma" na música popular do Brasil ${ }^{18}$. Pode-se dizer que o disco vem concretizar (e sintetizar) uma série de transformações culturais e musicais do período. Fato é que o álbum chegou ao mercado num momento culturalmente agitado. A inserção definitiva de um novo estrato social, a classe média urbana, no plano da criação e consumo de música popular, bem como o surgimento do meio televisivo como um novo veículo de circulação musical foram aspectos que potencializaram as tensões culturais e os debates estéticos desenvolvidos ao longo da efervescente década de I960.

No plano musical, o álbum de João Gilberto parece ter efetivamente sintetizado uma série de processos pelos quais a música popular - em especial os "sons das boates de Copacabana"ז9 - vinha passando desde fins dos anos I940. É possível destacar alguns aspectos gerais desse trabalho: harmonias repletas de "acordes dissonantes", próximas de estilos jazzísticos; um novo estilo "violonístico" de acompanhamento - a famosa "batida" de bossa nova -, que incorporava aspectos do samba, do bolero

I8 Já são muitos os trabalhos acadêmicos e jornalísticos sobre o tema. Ver, entre muitos outros: CAMPOS, Augusto de. Balanço da bossa e outras bossas. 4. ed. São Paulo: Perspectiva, I986; CASTRO, Ruy. Chega de saudade: a história e as histórias da bossa nova. São Paulo: Companhia das Letras, I990; MAMMİ, Lorenzo. João Gilberto e o Projeto Utópico da Bossa Nova. Revista Novos Estudos Cebrap, n. 34, São Paulo, I992; GARCIA, Walter. Bim Bom: a contradição sem conflitos de João Gilberto. São Paulo: Paz Terra, I999.

I9 Com o fechamento dos cassinos em I946, o bairro de Copacabana se tornou, a partir da década de I950, o novo espaço da boemia no Rio de Janeiro. O grande número de restaurantes, bares e boates do bairro era frequentado por jovens, artistas e intelectuais responsáveis por movimentar consideravelmente a vida noturna da região. A música popular executada nesses recintos possuiria alguns aspectos de sonoridade identificados como "modernos”, em consonância com certa aura de "sofisticação" própria ao bairro e suas boates. A incorporação explícita de procedimentos jazzísticos nesse repertório, principalmente de estilos do jazz moderno (a exemplo do bebop, do hard bop e do west coast), um signo de modernidade, era o principal fator de diferenciação desse repertório. Para mais informações, ver: ZAN, José Roberto. Do fundo de quintal à vanguarda: contribuição para uma história social da música popular brasileira. Tese (Doutorado em Sociologia). Instituto de Filosofia e Ciências Humanas, Universidade Estadual de Campinas, I997; SARAIVA, Joana Martins. A invenção do sambajazz: discursos sobre a cena musical de Copacabana no final dos anos de I950 e início dos anos I960. Dissertação (Mestrado em História). Programa de Pós-Graduação em História Social da Cultura, Pontifícia Universidade Católica do Rio de Janeiro, Rio de Janeiro, 2007. 
e do jazz; uma nova interpretação no canto, marcado pelo despojamento, pela ausência de ornamentações e pela proximidade com a fala, em contraste com o estilo "operístico" e grandiloquente predominante dos cantores (as) de maior destaque na "era do rádio”; uma nova maneira de articular o acompanhamento violonístico ao canto, em que prevalece o diálogo e a interação entre melodia e acompanhamento; uma nova concepção de arranjo musical, em que passa a predominar um caráter contrapontístico, horizontal e "econômico" (uso, contido, de poucos instrumentos), que, não raro, faz alusão a elementos da própria melodia e letra das canções ${ }^{20}$. Outro aspecto relevante desse repertório consiste em certo caráter "camerístico", de "elaboração progressiva” e anticontrastante, que teria ligação com a música erudita impressionista, por um lado, mas também com os próprios locais de criação e execução dessa música, os apartamentos e boates da zona sul carioca ${ }^{21}$. Em relação às letras das canções bossa-novistas, elas seriam marcadas por um tipo de vocabulário simples, de temáticas cotidianas, também pelo intimismo, por uma "ironia leve" e por certa espontaneidade ${ }^{22}$. As temáticas das canções seriam caracterizadas por uma "leveza" e "impessoalidade" e poderiam ser rotuladas como "músicas de situação", muito distintas das canções de aspecto narrativo e sentimental que predominaram nos discos e no meio radiofônico das décadas anteriores. Ademais, são recorrentes nesse repertório os jogos de linguagem, em que a música comenta a si própria, e certo senso de humor, bem como o uso de versos curtos com vocabulário simples e reduzido ${ }^{23}$.

Predomina no disco um repertório de canções em que a centralidade é dada pela letra e pela melodia. O acompanhamento é centrado no violão, escoltado pela percussão executada de maneira discreta. Outros instrumentos melódicos e harmônicos, como o trombone, a flauta e o piano, possuem, muita vez, função contrapontística, realizando "contracantos" e "comentários" melódicos referenciados na melodia da canção. É possível, em boa medida, argumentar que o álbum Chega de saudade reuniu uma série de procedimentos e práticas que vinham sendo explorados por músicos que atuavam nos espaços da zona sul do Rio de Janeiro. Também, muitos elementos relativos a certa "tradição" da música popular urbana - elementos ligados a gêneros como o samba e o choro - estariam presentes nesse repertório, ainda que reprocessados, relidos, a partir de novos parâmetros musicais. De outro lado, elementos e procedimentos oriundos do jazz também estariam presentes, ainda que relativizados, por assim dizer, uma vez que não são empregados através de colagens e apropriações simples. Isso ocorreria principalmente quando observados os trabalhos

20 Para mais informações, ver: SANTOS, Fábio Saito dos. "Estamos aî": um estudo das influências do jazz na bossa nova. Dissertação (Mestrado em Música). Instituto de Artes, Universidade Estadual de Campinas, Campinas, 2006; MAMMİ, Lorenzo, I992, op. cit.; BRITO, Brasil Rocha. Bossa Nova. In: CAMPOS, Augusto de. Balanço da bossa e outras bossas. 4. ed. São Paulo: Perspectiva, I986; GARCIA, Walter, op. cit.

2I MEDAGLIA, Júlio. Balanço da bossa. In: CAMPOS, Augusto de. Balanço da bossa e outras bossas. 4. ed. São Paulo: Perspectiva, I986; BRITO, Brasil Rocha, op. cit.

22 MEDAGLIA, Júlio, op. cit.

23 SANT’ANNA, Afonso Romano de. Música popular e moderna poesia brasileira. Rio de Janeiro: Vozes, I986. 
de João Gilberto e de Tom Jobim²4. Haveria aí, pois, certa apropriação seletiva de alguns aspectos jazzísticos genéricos - principalmente em relação à instrumentação e a alguns detalhes harmônicos e melódicos ${ }^{25}$.

A sonoridade da bossa nova pode ser associada a tendências mais gerais do próprio contexto sócio-histórico. O governo de Juscelino Kubitschek (I956 a I96I), marcado pelo Programa de Metas, pela promessa de grande desenvolvimento do país e pelos avanços na industrialização, contribuiu "para criar, em amplos setores da população, um certo otimismo com relação à modernização da sociedade brasileira" ${ }^{26}$. Tal sentimento pode ter sido reforçado por outros fatores, como a mobilização de importantes intelectuais nacionalistas ao redor do Instituto Superior de Estudos Brasileiros (Iseb), empenhados em produzir ideologias confluentes com o desenvolvimentismo de Kubitschek, bem como pela própria construção de Brasília, nova capital federal, projetada pelos arquitetos Oscar Niemeyer e Lucio Costa, que simbolizava a chegada de um novo momento, moderno, pois, ao país. Nesse sentido, como nos diz Zan, a "confiança que a política econômica despertava em amplos setores de classe média e a aura democrática do governo $\mathrm{JK}$, que procurava se diferenciar do populismo de massa do período getulista, guardam alguma relação com a 'leveza' que caracterizava o estilo das canções bossa-novistas” ${ }^{27}$.

\section{Novos RUMOS DA BOSSA}

Nos últimos anos de I950 e início da década seguinte, na esteira do impacto musical causado pelo disco de João Gilberto, a cantora Nara Leão continuou a atuar com alguma regularidade no cenário musical carioca e, eventualmente, em São Paulo. A partir daquelas primeiras aparições, como coadjuvante, nas apresentações da "turma" da bossa nova, a cantora foi gradualmente tendo seu nome identificado a esse fenômeno musical. Algumas reportagens e acontecimentos do período retratam

24 Muitos trabalhos sobre a bossa nova têm destacado a maneira pela qual toda uma "atmosfera musical" jazzística foi incorporada pelos principais artistas ligados a esse repertório. Em certo sentido, tais estudos apontam que alguns procedimentos e práticas presentes em alguns estilos do jazz moderno (como o cool jazz e o west coast jazz, por exemplo) foram incorporados pelos músicos bossa-novistas a partir de uma espécie de "filtro bossa-nova”. Ou seja, aspectos gerais do jazz moderno teriam sido adaptados ao formato da canção popular brasileira, ao primado da relação melodia-letra, ao ritmo do samba, entre outras preferências musicais dos artistas bossa-novistas. Ver, entre outros: SANTOS, Fabio Saito dos, op. cit.; GARCIA, Walter, op. cit.

25 SANTOS, Fabio Saito dos, op. cit.; ver também: MAMMİ, Lorenzo, I992, op. cit.

26 ZAN, Jose Roberto, op. cit., p. пIO.

27 Ibidem, p. III. 
tal identificação ${ }^{28}$. No jornal Última hora, por exemplo, uma reportagem de I4 de setembro de I960 retrata a criação do Clube Bossa Nova, dando voz a Roberto Menescal, Ronaldo Bôscoli e Nara Leão ${ }^{29}$. Nesse período, Nara, Bôscoli e Menescal estavam participando do programa Balada, da TV Continental, comandado por Sérgio Ricardo, músico recém-incorporado ao meio bossa-novista. Tal participação rendeu críticas positivas à cantora, publicadas no Última hora em março de I960. No mesmo diário, em abril, Moisés Fuks teceu mais elogios à intérprete ${ }^{30}$. No ano seguinte, no mesmo periódico, Nara foi citada elogiosamente graças a sua apresentação com João Gilberto na Universidade Mackenzie, em São Paulo. Ricardo Amaral, colunista da filial paulista do diário, frisou que "Nara e João fizeram do público o que bem entenderam. Foram os verdadeiros donos da noite" ${ }^{31}$.

A própria intérprete, ao recordar essa fase de sua carreira, em depoimento ao MIS, sintetizou sua atuação nos primeiros anos da década da seguinte maneira: "[Houve] o disco do Carlinhos Lyra, um programa que teve numa televisão lá em São Paulo, não me lembro qual era, em que eu ia lá cantar músicas minhas. De vez em quando tinha uns shows em São Paulo, no Colégio Mackenzie. Fiz um com o João Gilberto, cantei com ele" ${ }^{32}$. Nota-se que a cantora destaca sua atuação em programas televisivos, os eventuais shows em São Paulo e a participação na gravação de um disco de Carlos Lyra, ocorrida entre I962 e I963, justamente sua estreia em produções fonográficas.

Essa primeira gravação da cantora está registrada no disco Depois do carnaval - o sambalanço de Carlos Lyra, terceiro trabalho de Lyra, lançado pela Philips em I963. O compositor, por sua vez, desde o início da década de I960, vinha traçando um caminho próprio e, gradativamente, distanciava-se das atividades ligadas aos músicos bossa-novistas. Lyra já não utilizava o termo bossa nova para rotular

28 Sérgio Cabral cita duas reportagens, ambas do Jornal do Brasil, de janeiro e fevereiro de I960, em que os jovens músicos bossa-novistas foram destaque. O nome de Nara Leão aparece em ambas; numa delas, contudo, a cantora é apresentada como a irmã de Danuza Wainer - em referência à sua irmã mais velha, Danuza Leão, modelo e figura marcante da alta sociedade carioca. CABRAL, Sérgio, op. cit., p. 47-48.

29 INSTALA-SE clube para defender “bossa nova”. Última hora, Rio de Janeiro, I4 de setembro de I960. Caderno 2, p. 2.

30 Críticas citadas por: CABRAL, Sergio, op. cit., p. 48.

3I AMARAL, Ricardo. Ricardo Amaral (Coluna). Última hora, Rio de Janeiro, 30 de junho de I96I. Caderno 2, p. I4.

32 LEÃO, Nara, 20I4, op. cit., p. 33. 
sua obra musical ${ }^{33}$, adotara a expressão "sambalanço" de modo a distinguir sua produção da dos demais jovens artistas. Como aponta Nelson Lins e Barros - um de seus principais parceiros à época -, na própria contracapa do disco, tal expressão era utilizada "para delinear, dentro do movimento, aquele sentido nacionalista que procura elevar o nível da música popular brasileira dentro de suas próprias fontes”34. O distanciamento de Lyra em relação à bossa nova esteve ligado a questões de ordem distintas: uma, mercadológica; e outra, de cunho estético e político. Em I959, graças a disputas de mercado envolvendo as gravadoras Philips e Odeon, que competiram na contratação de músicos ligados à bossa nova, Carlos Lyra firmou contrato com a Philips, atitude que desagradou seus companheiros, os quais tinham acordo verbal para a gravação de um disco coletivo pela Odeon, contando com a participação de Lyra. Isso teria causado um primeiro "racha" dentro do grupo bossa-novista. Por outro lado, a partir de seu segundo disco - Carlos Lyra (Philips, I96I) -, uma crescente preocupação em aludir à "realidade brasileira" e repensar a relação da bossa nova com as tradições musicais populares tornou-se presente. Tais questões, somadas a uma crescente politização artística, são explicitadas a partir de seu terceiro disco, que contou com a participação de Nara Leão ${ }^{35}$. A cantora acompanhou o compositor na interpretação das canções "É tão triste dizer adeus" e "Promessas de você", ambas resultado da parceria de Lyra com Lins e Barros.

O impacto do fenômeno bossa nova no meio musical, sua ampla repercussão nos meios midiáticos e os intensos debates da crítica em torno de suas particularidades contribuíram, de certo modo, para que jornalistas, críticos, compositores, intérpretes e poetas formassem um meio artístico relativamente integrado em torno do “movimento". No início da década de I960, entretanto, algumas produções sinalizam o surgimento de uma dissidência dentro desse mesmo meio. Numa tentativa de politização e popularização da bossa nova, alguns compositores e intérpretes aderiram a uma postura de engajamento político. Esse viés foi ganhando mais contundência à medida que tais artistas aproximaram-se de setores da esquerda brasileira e do Centro Popular de Cultura da União Nacional dos Estudantes (o CPC da UNE).

Parte das produções de artistas como Carlos Lyra, Nelson Lins e Barros, Sérgio Ricardo, Geraldo Vandré, Vinícius de Moraes e Baden Powell indica o surgimento

33 Em I960, na mesma data da já citada Noite do amor, do sorriso e da flor, Carlos Lyra, com apoio da Philips, apresentou o Festival de Sambalanço, na Pontifícia Universidade Católica - PUC, contando com a participação de Vinícius de Moraes, Sylvinha Telles, Oscar Castro Neves e Juca Chaves. O uso do termo "sambalanço" para designar o show bem como o repertório de seu primeiro disco, de I959, já apontam para uma divergência de direcionamento de Lyra em relação a seus parceiros bossa-novistas. O compositor foi quem primeiro repensou a relação da bossa nova com os repertórios musicais anteriores e, de certo modo, rompeu com ela rumo à politização da canção nos primeiros anos da década seguinte. Para mais detalhes, ver: SOUZA, Miliandre Garcia. Do teatro militante à música engajada: a experiência do CPC da UNE (I958-I964). São Paulo: Fundação Perseu Abramo, 2007.

34 LINS E BARROS, Nelson. Texto da contracapa do disco Depois do carnaval... In: LYRA, Carlos. Depois do carnaval... Philips, I963, I disco sonoro.

35 Tais questões marcaram a produção de Lyra nos anos seguintes. SOUZA, Miliandre Garcia, op. cit., p. 94-I09. 
de nova vertente musical ${ }^{36}$. Tanto as temáticas retratadas em muitas de suas canções no período quanto alguns aspectos propriamente musicais possuem certas características que as distinguiram do estilo bossa-novista que até então predominava: a maneira de executar o violão no “acompanhamento" musical é dotada de uma acentuação mais forte, com timbragem mais "suja”, distanciando-se da "batida" de bossa nova; o uso de instrumentos de percussão pouco comuns ao repertório bossa-novista, como o bongô, o pandeiro e o atabaque; o diálogo com diferentes ritmos e gêneros musicais; a inclusão de temáticas relacionadas a problemas sociais e a tradições populares (que em muito diferem dos temas "leves", do cotidiano "zona sul”, da estética do "mar, amor, sorriso, flor”); a gravação de canções compostas como trilhas sonoras de peças teatrais e filmes. Vale ressaltar que muitos elementos dessas produções, como certos padrões interpretativos, estruturação harmônica e mesmo boa parte da instrumentação, guardam proximidade com o estilo bossa-novista.

Pode-se afirmar que nesse repertório encontravam-se reprocessadas, em alguma medida, certas "conquistas estéticas" da bossa nova, articuladas a aspectos musicais que remetiam a tradições musicais populares e a temáticas relacionadas a problemas sociais. Dito de outro modo, esse grupo de músicos vai se empenhar num movimento de articulação das "raízes e tradições populares" com certa "sofisticação e modernidade” bossa-novista. E, à medida que tais artistas iam se aproximando de setores da esquerda por meio de instituições políticas e culturais, crescia a tendência de engajamento político e a busca de maior popularização de suas produções.

\section{“EX-MUSA" DA bOSSA NOVA E A ESTREIA “OFICIAL"}

A partir de I962, as escolhas efetuadas por Nara Leão evidenciam a busca de novos caminhos artísticos. Tem-se como exemplo a negativa dada pela cantora em relação a uma possível participação no famoso show de bossa nova em Nova York, ocorrido no Carnegie Hall37, bem como a própria participação da cantora na gravação do já citado LP de Carlos Lyra, aproximando-a, assim, daquela nova vertente musical que já se diferenciava da bossa nova rumo a uma "politização” da canção. Dessa contribuição com Lyra seria natural presumir uma possível influência no distanciamento de Nara

36 Algumas composições dos primeiros anos de I960, como "Zelão", de Sérgio Ricardo, "Quem quiser encontrar o amor" e "Aruanda”, ambas de Carlos Lyra e Geraldo Vandré, "Marcha da quarta-feira de cinzas”, de Lyra e Vinícius de Moraes, “Maria do Maranhão”, de Lyra e Nelson Lins e Barros, os afrossambas de Baden Powell e Vinícius de Moraes, entre outras produções, servem de exemplo para demonstrar essa nova vertente. SOUZA, Miliandre Garcia, op. cit., p. IO7-II4; ZAN, Jose Roberto, op. cit., p. I29-I3I.

37 Segundo Sérgio Cabral, o nome de Nara constava entre os participantes da famosa apresentação, contudo, após uma conversa com Sylvinha Telles, ambas recusaram o convite dos organizadores abrindo mão de sua participação no show. CABRAL, Sérgio, op. cit., p. 56. 
em relação à bossa nova ${ }^{38}$, porém, como afirmou o próprio compositor em entrevista a Sérgio Cabral, "Quem politizou a Nara foi o cinema novo"39. De fato, seu namoro com o cineasta moçambicano Ruy Guerra, iniciado também em I962, a aproximou de artistas intelectualizados ligados ao cinema novo, como Nelson Pereira dos Santos, Gláuber Rocha e Cacá Diegues $4^{\circ}$. Foi possivelmente tal aproximação que despertou em Nara o interesse por questões voltadas às distintas realidades sociais brasileiras e uma busca de novos caminhos artísticos.

Essas experiências de Nara não mais restritas ao repertório bossa-novista se concretizaram com sua atuação no show Trailer, composto pelas canções da peça Pobre menina rica, de Vinícius de Moraes e Carlos Lyra, e que estreou em 28 de março de I963, na boate Au Bon Gourmet, do empresário Flavio Ramos, sob a direção e produção de Aloysio de Oliveira e Eumir Deodato. A apresentação funcionou como uma espécie de prólogo da referida peça e contou com a presença da cantora, dos dois compositores e do conjunto musical liderado por Roberto Menescal ${ }^{4 \mathrm{I}}$. A performance da cantora rendeu positivos comentários na imprensa. Em uma coluna social do Última hora, assinada por Jacinto de Thormes, pseudônimo do jornalista Maneco Müller, lia-se: "Nara Leão, em estreia profissional, mostra que tem boa voz e muita bossa, além de não demonstrar qualquer nervosismo"42. No mesmo jornal, Thereza Cesario Alvim também citou positivamente a participação da cantora, que teria surpreendido parte da plateia:

Nara Leão esteve ótima. Era a “jeune-fille” prendada que, a pedidos da família, cantava para os amigos. E os amigos gostaram. Muito. Nara tem boa voz para cantar samba e um charme excepcional. Os amigos que esperavam, com um ar condescendente, aplaudir um pouco a menina só porque Vinícius e Carlinhos a estavam prestigiando tiveram uma surpresa. Ela foi quase tão aplaudida quanto os dois. Nara está lançada.43

38 Vale ressaltar que Nara Leão havia se afastado de Ronaldo Bôscoli, figura sempre presente nas apresentações de bossa nova, por motivações de ordem afetiva: em I96I, Bôscoli, então noivo de Nara, teria se envolvido com a intérprete Maysa durante turnê dela pela América Latina. Ao retornarem ao Brasil, Maysa chegou a declarar à imprensa que se casaria com Bôscoli. O desagrado de Nara em relação ao ocorrido contribuiu para seu afastamento de Bôscoli e, em alguma medida, pode ter contribuído também para seu desinteresse por continuar vinculada à "turma" da bossa.

39 CABRAL, Sérgio, op. cit., p. 57.

40 Vale ressaltar que nesse período Nara continuou a se apresentar ocasionalmente com músicos ligados à bossa nova. No Diário de notícias, em 20 de dezembro de I962, divulgou-se o Festival Carioca da Bossa Nova, organizado por Flávio Ramos em sua boate, Au Bon Gourmet. O festival contou com a presença de Sérgio Mendes, Tamba Trio, Roberto Menescal, Vinícius de Moares, Baden Powell e Nara Leão, referida, nessa e em outras muitas ocasiões, como a “irmã de Danuza Leão”. MACHADO, Ney. Festival da bossa nova no Bon Gourmet. Diário de notícias, Rio de Janeiro, 20 de dezembro de I962. Segunda seção, p. 4. Sérgio Cabral também cita uma apresentação da cantora, no mesmo mês, ocorrida em Salvador.

4I PAIVA, Maurício de. Roteiro do Rio. Última hora, Rio de Janeiro, 29 de março de I963. Caderno 2.

42 THORMES, Jacinto de. Sociedade e adjacências. Última hora, Rio de Janeiro, 30 de março de I963. Caderno 2.

43 ALVIM, Thereza Cesario. A bossa como ela é. Última hora, Rio de Janeiro, Io de abril de I963. Caderno 2. 
Possivelmente graças à positiva repercussão de Trailer, ou mesmo por conta da relevância artística dos autores das canções, Nara, muita vez, declarou que sua estreia como cantora havia ocorrido efetivamente no dia 28 de março de I963, apesar de ter participado anteriormente de muitas outras apresentações em público, como já visto. De todo modo, esse show pode ser considerado como um marco na carreira da intérprete, na medida em que parece ter contribuído para consolidar novos rumos de sua trajetória. Processo esse que vai culminar, poucos meses depois, na produção de seu primeiro disco, cujos trabalhos tiveram início ainda em agosto.

De fato, foi somente em fevereiro de 1964 que a intérprete - a essa altura não raro referida como a "musa da bossa nova" - apareceu para um público mais amplo. Nesse mês foi lançado seu primeiro disco, Nara, pela gravadora Elenco. Em consonância com os novos rumos da "moderna música popular" e contrariando a posição de "musa", o repertório e a sonoridade contidos nesse trabalho não condiziam com aquilo que se poderia esperar de um disco, por assim dizer, de bossa nova. O som "intimista" e as temáticas leves - "o amor, o sorriso e a flor" - davam lugar a outras questões. A busca de outros caminhos artísticos, sua aproximação a Carlos Lyra e seu contato com os artistas do cinema novo, enfim, tomavam forma. Daí uma verdadeira guinada na trajetória da intérprete, que de certo modo contribuiu para estabelecer novas diretrizes para a música brasileira popular. O texto da contracapa do disco, assinado pelo diretor artístico e proprietário da gravadora, Aloysio de Oliveira, diz o seguinte: "a moça Nara Leão tem sido, desde os primeiros passos da bossa nova, uma espécie de musa do movimento [...] o seu lançamento neste disco foge, em seu estilo, da bossa nova propriamente dita, para um repertório variado que inclui músicas que nada têm a ver com a bossa nova"44. O repertório do disco - composto de sambas de Nelson Cavaquinho, de Cartola e de Zé Kéti, bem como de canções que tematizavam questões sociais e se remetiam a tradições musicais populares, a exemplo de "Canção da terra", de Edu Lobo e Ruy Guerra, e "Berimbau”, de Baden Powell e Vinícius de Moraes - é representativo do estabelecimento de um novo segmento de canção popular.

\section{NARA: PERFORMANCE NO PRIMEIRO DISCO}

Uma apreciação do disco revela, em termos gerais, tanto a presença de elementos que podem ser identificados como característicos do estilo bossa-nova quanto um considerável número de aspectos que aludem a outros referenciais musicais. Partindo das temáticas e dos diferentes estilos musicais dos fonogramas, foi possível agrupá-los em torno de algumas características comuns: I) canções que poderiam ser classificadas estilisticamente como "bossa nova nacionalista" - seriam as canções "Marcha da quarta-feira de cinzas”, de Carlos Lyra e Vinícius de Moraes, “Feio, não é bonito", de Carlos Lyra e Gianfrancesco Guarnieri, e "Consolação”, de Baden Powell e Vinícius de Moraes -, cujas temáticas e sonoridade, além de se remeterem à bossa nova, seriam representativas de uma abertura bossa-novista rumo a gêneros e

44 OLIVEIRA, Aloysio. Texto da contracapa do disco Nara. In: LEÃO, Nara. Nara. Rio de Janeiro: Elenco, I964. I disco sonoro. 
elementos musicais pouco comuns à sua fase "heroica", do mesmo modo que seus temas já se distanciam da "leveza", da "afetividade" e daquela ambientação "solar" próprias à bossa nova; 2) canções representativas daquilo que se nomeou "samba de morro", dada a origem social de seus compositores - "Diz que fui por aí", de Zé Kéti e H. Rocha, "O sol nascerá (A sorrir)", de Cartola e Elton Medeiros, e "Luz Negra”, de Nelson Cavaquinho e Irani Barros -, uma vez que os próprios artistas do período costumavam rotular tais composições dessa maneira, a despeito dos distintos estilos composicionais adotados pelos diferentes sambistas; 3 ) canções de cunho mais passional, de temática amorosa, porém, marcadas por certo sentimento de perda, de sofrimento, e pela impossibilidade de qualquer tipo de perdão ou redenção - "Vou por aí", de Baden Powell e Aloysio de Oliveira, e "Réquiem para um amor”, de Edu Lobo e Ruy Guerra; 4) canções em que predominam temáticas sociais e referências às tradições populares, principalmente àquelas de matriz afro-brasileira - "Canção da terra", de Edu Lobo e Ruy Guerra, "Berimbau”, de Baden Powell e Vinícius de Moraes, e "Maria moita", de Carlos Lyra e Vinícius de Moraes -, questões como liberdade, trabalho, desigualdade, luta e sofrimento são centrais nessas composições. Por fim, a última faixa do disco, "Nanã”, de Moacyr Santos e Mário Telles, pode ser considerada uma exceção em relação a esses conjuntos, principalmente por se tratar de um fonograma somente instrumental. Ainda que haja relação entre a obra de Santos, seu compositor e arranjador, e as tradições e musicalidades afro-brasileiras - principalmente em seus aspectos rítmicos e elementos percussivos -, a ausência de letra a distingue das demais.

Vale salientar que tal divisão não se pretende arbitrária e nem propõe uma fixação ou rotulação dos fonogramas de tipo reducionista. Resulta evidente que tais canções poderiam, mesmo dentro dessa mesma divisão, ocupar mais de um conjunto específico. Optamos por assim classificá-las para melhor traduzir a diversidade dessa produção: seja pelas diferenças temáticas das composições e por suas características no que se refere aos arranjos musicais, seja por seus estilos, por seus gêneros e por sua variação rítmica.

Em linhas gerais, os arranjos musicais contidos no disco, a cargo de Lindolpho Gaya, guardam certa proximidade com os arranjos típicos da bossa nova, a exemplo dos arranjos de Jobim para o primeiro disco de João Gilberto. Prevalece, assim, certa "economia", por assim dizer, nas intervenções instrumentais - backgrounds e contracantos -, seja dos naipes de cordas e de sopros (madeiras e metais), seja no acompanhamento executado por bateria, percussão, baixo, violão e piano. É possível argumentar que os arranjos encontram-se sempre a serviço do canto, atrelados às melodias das canções, contribuindo para pôr em evidência os próprios conteúdos textuais (as "letras") das composições. Assim, cordas, metais e madeiras, via de regra, dialogam, de maneira camerística, com trechos da melodia, bem como "preenchem" alguns espaços - pausas - deixados pelo canto, além de realizarem backgrounds. Os coros vocais, masculino e feminino, também aparecem em vários fonogramas, executando algumas estrofes ou pequenos trechos do texto, revezando-se com a voz de Nara, e raramente executam backgrounds harmônicos. O acompanhamento - a 
“cozinha"45 -, a cargo do baixo, da bateria, da percussão e do violão, é realizado de maneira sutil, muito distante do dito "samba-jazz" 46 em termos de sonoridade, de timbre e intensidade na maneira de executar os instrumentos. O piano também é executado de maneira muito "econômica", funcionando muito mais como instrumento melódico, ao realizar contracantos e intervenções melódicas, do que executando acordes ritmicamente - "levadas" - numa função típica de acompanhamento musical.

$\mathrm{Na}$ abertura do disco - "Marcha da quarta-feira de cinzas" - ouve-se uma marcha-rancho, tradicional gênero musical carnavalesco. $\mathrm{O}$ arranjo e a orquestração do maestro Gaya para o referido fonograma são caracterizados por típicos backgrounds executados pelo naipe de cordas, por intervenções e contracantos do trombone e pelo coro vocal feminino - responsável pela interpretação de algumas estrofes da canção. De certo modo, o arranjo e o ritmo da canção remetem o ouvinte a repertórios anteriores à bossa nova, exceção feita ao canto de Nara Leão e sua proximidade com a fala e sua emissão leve e coloquial. Há na temática da canção um tom de tristeza mais profunda que em canções típicas da bossa nova, um lamento mais "carregado". Contudo, a "promessa de felicidade", o fim da tristeza e o perdão - tão presente nas letras de Vinícius de Moraes - dão o tom da segunda parte da canção, principalmente em suas últimas três estrofes ${ }^{4}$.

Nessa mesma linha, na terceira faixa do disco, “Feio, não é bonito”, um samba estilizado - nem "samba de morro", nem "samba tradicional", nem "samba bossanova", ouve-se essa combinação de arranjos musicais "econômicos" - agora com um acompanhamento mais típico da bossa nova (violão, contrabaixo acústico e bateria) - com uma temática com certo apelo político, por assim dizer. Problemas sociais, tradições populares, tristeza são personificados pelo morro, pelo "choro alegre" e "canto triste" que dali ecoam. Tais imagens são transmitidas pela letra e pelo próprio movimento melódico da canção. O conjunto de notas em torno da nota mi (as notas dó, ré e fá), que efetua uma ornamentação desta por movimentos de bordaduras, isto é, movimentos de grau conjunto, cujos repousos ocorrem na nota mi (ver figura I), sobre uma harmonia descendente iniciada e finalizada em lá menor (Am6-G\# ${ }^{0}(b I 3)-$

45 Termo utilizado no jargão musical para discernir as funções de acompanhamento musical - harmônico e rítmico -, normalmente a cargo, na música popular, de contrabaixistas, bateristas, percussionistas, violonistas/guitarristas e/ou pianistas.

46 O estilo posteriormente batizado como "samba-jazz” ou “jazz-samba” refere-se à produção dos pequenos conjuntos musicais - trios e quartetos, principalmente - característicos das pequenas boates de Copacabana, como já citado, que exploravam repertórios cavados em uma sonoridade caracterizada pela combinação de procedimentos do dito "jazz moderno" (bebop, hard bop e cool jazz), com elementos do samba e da bossa nova. Ademais, as instrumentações menores baseadas no trio de piano, baixo e bateria, muita vez acrescidas de um ou mais instrumento de sopro, os chamados “combos”, característicos dos estilos do jazz moderno, ganharam destaque a partir do bebop por propiciar maiores espaços para improvisação e interação entre músicos. GRIDLEY, Mark C. Jazz styles: history and analysis. 7. ed. New Jersey: Prentice Hall, I999.

47 Como exemplo, a letra da primeira estrofe da canção: "Acabou nosso carnaval/ Ninguém ouve cantar canções/ Ninguém passa mais brincando feliz/ E nos corações, saudades e cinzas foi o que restou”; e a letra da quarta estrofe: "A tristeza que a gente tem/ Qualquer dia vai se acabar/ Todos vão sorrir, voltou a esperança/ É o povo que dança, contente da vida, feliz a cantar”. In: LEÃO, Nara, I964, op. cit. 
$\left.C_{7} / G-G b 7-F 7 M-E 7(b 9)-A m 7\right)$, é transposto com o mesmo desenho melódico a cada nova estrofe: primeiro uma terça menor acima (ver figura 2), nota sol ornamentada por fá e lá e harmonizada por $C_{7} M-G 7(\# 5)-G m 7-A / G-G m 7-A / G-E m 7\left(b_{5}\right)$, seguido de nova ascensão de um tom (ver figura 3), nota lá ornamentada por sol e sib e harmonizada pela variância entre $\mathrm{Dm} 7 \mathrm{e} \mathrm{Bbm6}$, chegando ao clímax na nota dó (ver figura 4), quando o desenho melódico de ornamentações repete-se apenas uma vez (dó é ornamentado por si e ré), sendo substituído por um movimento por grau conjunto descendente (de ré a mi) seguido de dois saltos melódicos ( $\uparrow \mathrm{mi}$ - dó e $\downarrow$ dó - sol- sol\#) e de uma bordadura (sol\# - si) cuja resolução ocorre na nota lá (com a harmonia retornando ao $\mathrm{Am}$ ).

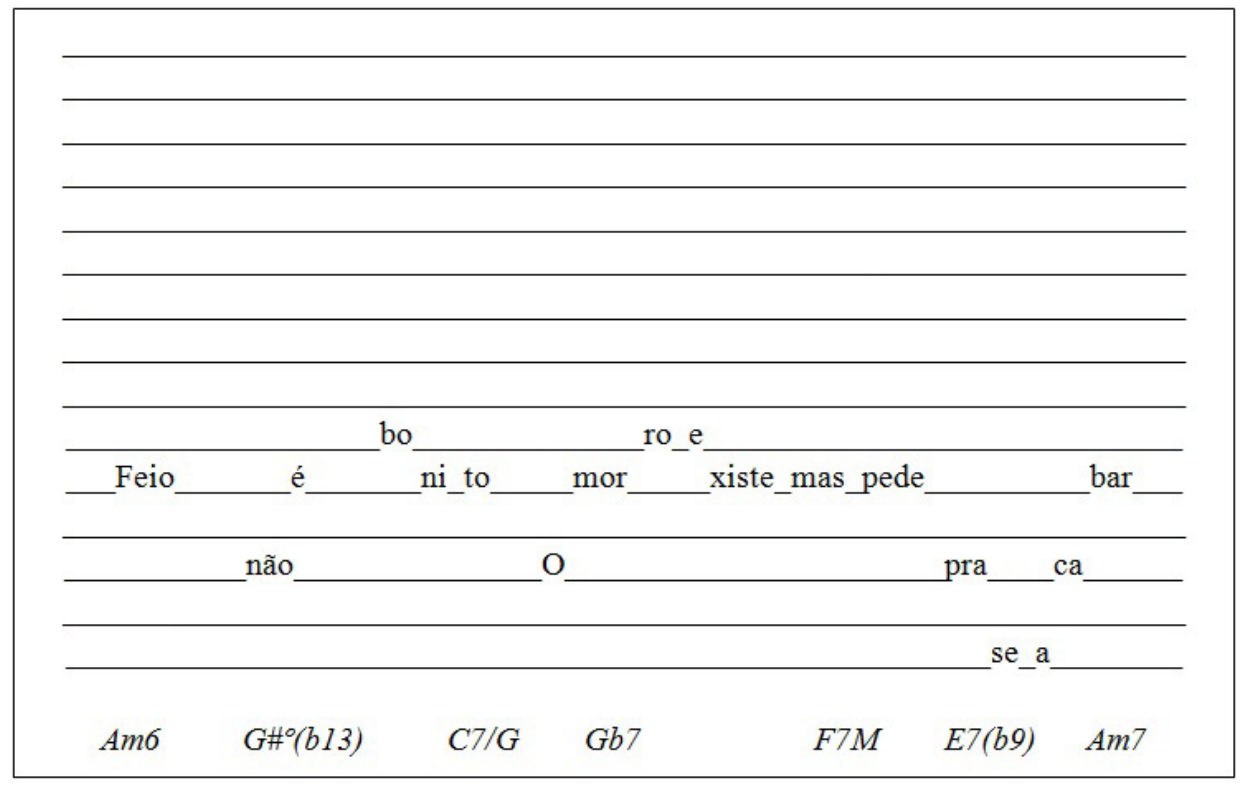

Figura I - Diagrama da melodia, letra e harmonia de trecho de “Feio, não é bonito”48

48 Cada linha do diagrama representa uma nota, iniciando-se na nota dó (primeira linha inferior) e subindo um semitom a cada linha superior (a palavra "feio" é cantada, portanto, em mi). Abaixo está indicada, por meio de cifras, a harmonia simplificada do referido trecho musical. Esse diagrama é inspirado no trabalho analítico de Luiz Tatit. Ver, por exemplo: TATIT, Luiz; LOPES, Ivã Carlos. Elos de melodia e letra: análise semiótica de seis canções. Cotia: Ateliê Editorial, 2008. 


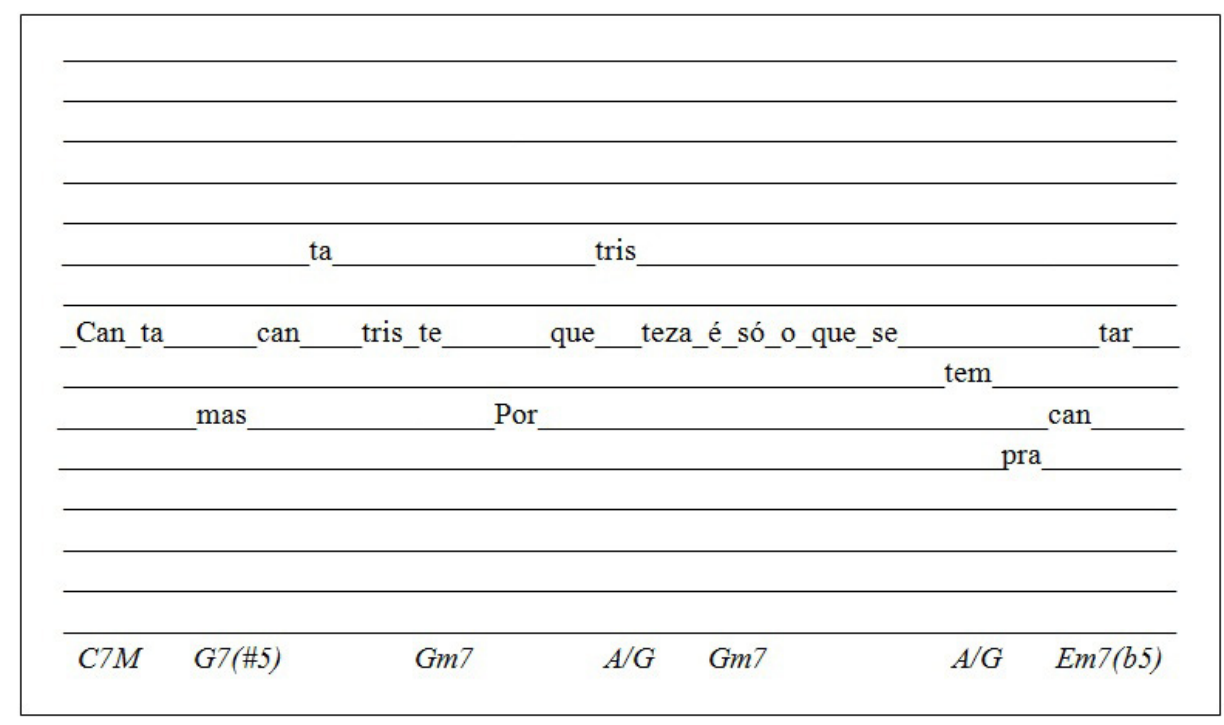

Figura 2 - Diagrama da melodia, letra e harmonia do segundo trecho de "Feio, não é bonito"

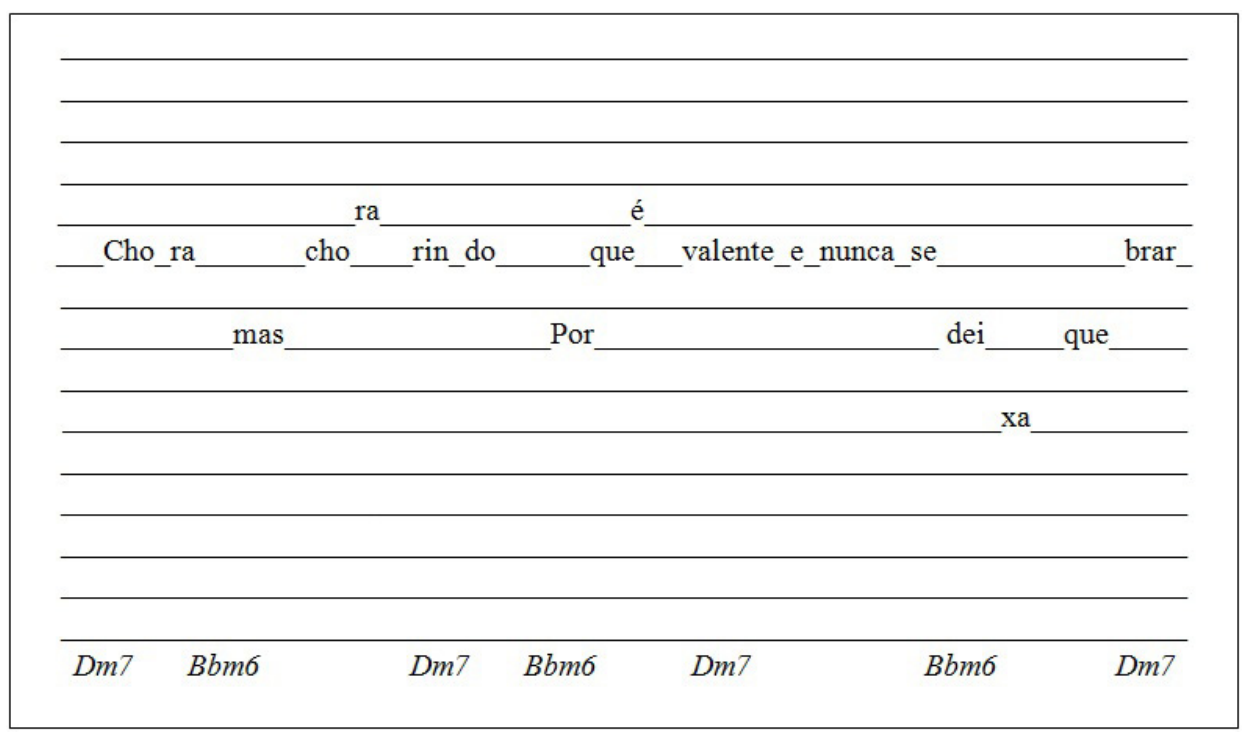

Figura 3 - Diagrama da melodia, letra e harmonia do terceiro trecho de "Feio, não é bonito" 


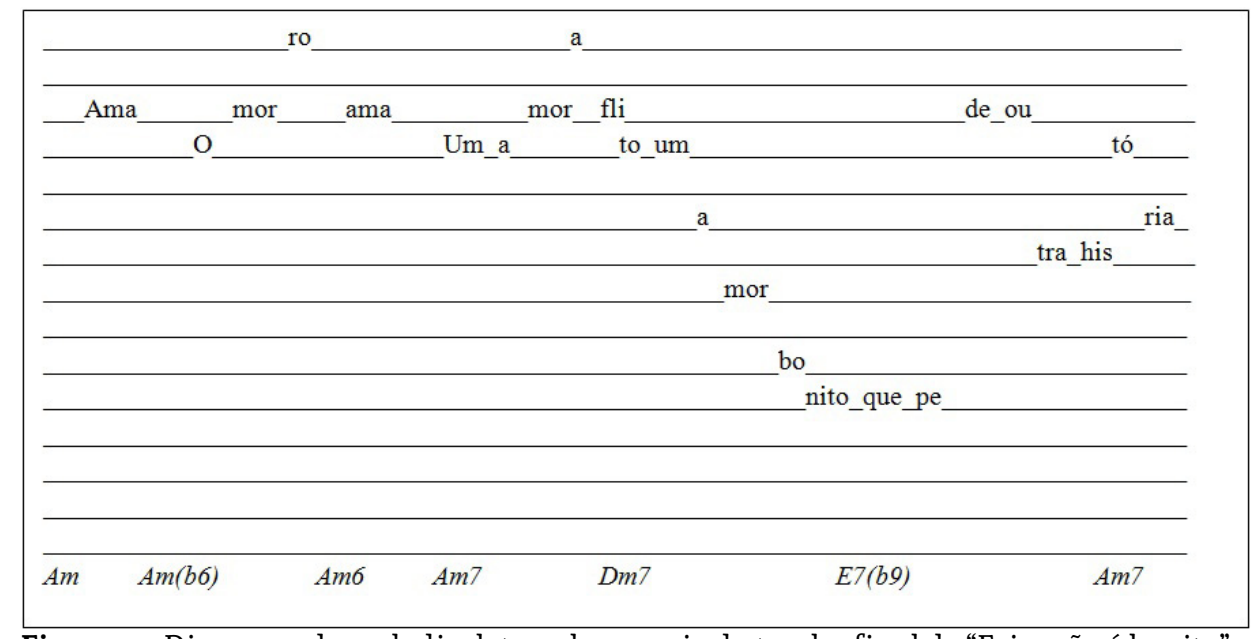

Figura 4-Diagrama da melodia, letra e harmonia do trecho final de "Feio, não é bonito"

Tal movimento melódico e harmônico vai imprimindo uma crescente tensão ao sentido (musical) da canção. As transposições ascendentes no desenho da melodia fazem com que a cada nova estrofe a tensão seja maior. "Letra" e "música", num mesmo movimento tensivo crescente, colaboram assim para um mesmo sentido e significado, que também é explicitado pela maneira de entoar de Nara Leão e do coro vocal. De outro modo, pode-se dizer que é através da performance vocal, efetuando e unificando esses dois polos que constituem o mesmo o eixo formal da canção ("letra" e "música"), que tal movimento de fato se realiza. Após essa direção crescente, segue-se aquele desenho melódico descendente e a resolução, harmônica e melódica. Tal momento "musical" refere-se, na "letra" (e vice-versa), ao pedido de resolução das aflições históricas do morro ${ }^{49}$. Nesses termos, a canção talvez corresponda àquele estilo que Marcos Napolitano e outros autores nomearam como "bossa nova engajada"50.

O primeiro "samba de morro" do disco, talvez o primeiro a ser gravado por essa geração de artistas, "Diz que fui por aí", é a faixa de número dois. Assim, à marchinha pós-bossa nova ("Marcha da quarta-feira de cinzas") segue-se o samba de Zé Keti e seu retrato da vida boêmia na visão de um malandro apaixonado (pela "madrugada" e por "ela") ${ }^{5 \text {. }}$ Se, quando surge a bossa nova, "morre o botequim como lugar de criação da

49 Trecho da letra de "Feio, não é bonito", primeira parte: “Feio, não é bonito / O morro existe/ Mas pede pra se acabar”; segunda: “Canta, mas canta triste/ Porque tristeza/ É só o que se tem pra contar”; terceira: “Chora, mas chora rindo/ Porque é valente/ E nunca se deixa quebrar"; e a última: "Ama, o morro ama/ Um amor aflito, um amor bonito/ Que pede outra história”. In: LEÃO, Nara, I964, op. cit.

50 NAPOLITANO, Marcos. A síncope das ideias. São Paulo: Fundação Perseu Abramo, 2007.

5I Trecho da letra de "Diz que fui por aí": "Se alguém perguntar por mim/ Diz que fui por aí/ Levando o violão debaixo do braço/ Em qualquer esquina eu paro/ [...] Tenho um violão para me acompanhar/ Tenho muitos amigos, eu sou popular/ Tenho a madrugada como companheira/ [...] Eu estou na cidade, eu estou na favela/Eu estou por aí/ Sempre pensando nela”. In: LEÃO, Nara, I964, op. cit. 
música popular" ${ }^{2}$, dando lugar aos apartamentos e boates, há aqui um cruzamento entre apartamento e "botequim", entre Portela e Avenida Atlântica. Pela voz de Nara Leão, Zé Keti retoma algumas temáticas comuns ao universo boêmio tantas vezes retratado pelos sambas de décadas anteriores. No entanto, o gesto interpretativo da jovem cantora pouco se aproxima da maneira de cantar dos grandes cartazes do rádio, principais intérpretes da boemia e malandragem dos sambas cariocas. Nara quase não usa vibrato, sua emissão é pouquíssimo tensa e, à exceção de pequenos e sutis glissandos, não ornamenta sua voz. Sua emissão é leve, relaxada, extremamente próxima da fala. Os prolongamentos melódico-entoativos ocorrem somente em obediência à melodia da canção. $\mathrm{O}$ acompanhamento do samba aqui já não é executado pelos típicos "regionais" - com o violão de sete cordas e suas "baixarias", guarnecido pelo cavaquinho, pandeiro, entre outros instrumentos - em seu lugar, um trio - que também não é exatamente aquele trio de "samba-jazz" - formado por bateria, contrabaixo e violão. As "convenções musicais", à maneira do "samba-jazz", marcam presença, ainda que sejam executadas de maneira muito mais sutil, menos estridente, assim como o arranjo, mais próximos, ambos, da bossa nova que do hard bop. Ademais, é no violão de Geraldo Wesper que reside grande contraste com os sambas gravados em décadas anteriores. No lugar das graves "baixarias", comentários melódicos agudos - já que há um contrabaixo acústico para "preencher" os graves, ainda que este também não realize "baixarias”. Do mesmo modo, as tríades e tétrades são substituídas por acordes estendidos e "dissonantes", de sonoridade jazzística, por assim dizer. Em suma, a centralidade ainda está nesse jogo entre violão e voz, mas não tanto numa relação orgânica, que beira a perfeição, entre violão e canto minuciosamente colocados "ou pendurados" um no outro, como faz João Gilberto, na opinião de Lorenzo Mammǐ3. O violão de Wesper é mais jazzístico, sua síncope é mais marcada. O canto de Nara, ainda que muito referenciado na emissão contínua, falada e rarefeita de Gilberto, ao dar voz a esse e outros sambas - "Opinião", "Acender as velas", "Luz negra”, "Pedro pedreiro" etc. -, acaba por tensionar cada vez mais a moderna canção popular nascida da bossa nova. A aura bossa-novista vai dando lugar a certa estridência.

O outro conjunto de canções presentes no disco - de cunho mais passional, pode-se dizer - é composto por "Réquiem para um amor" e "Vou por aí". Em ambas, o tema amoroso guarda pouca semelhança com canções bossa-novistas típicas em termos de composição, tratamento e interpretação. Se em "Chega de saudade" toda a segunda parte era redentora, anunciando um perdão e uma afetividade "sem ter fim", aqui, a perda é perda, o sofrimento é sofrimento, e nada mais. A voz, cuja assinatura é mais "passionalizada", com uma emissão tensa que tende à dramatização - uma melodia que estende as durações do canto -, é guarnecida pelo piano e pelo violão, que não efetuam um acompanhamento harmônico e rítmico - não há propriamente uma "levada" -, mas, sim, um acompanhamento melódico-harmônico, por assim dizer. As cordas e os instrumentos de sopro contribuem para esse "clima", realizando backgrounds e intervenções melódicas.

52 MAMMİ, Lorenzo, I992, op. cit., p. 63.

53 Ibidem, p. 67. 
Diante das diferenças temáticas e de gêneros musicais presentes no disco, o que dá unidade ao LP é principalmente o canto de Nara: seu gesto interpretativo, sua assinatura vocal, além de certos traços constantes no tratamento musical (arranjos, instrumentação e sonoridade). Sua emissão guarda forte ligação com a bossa nova, berço de sua musicalidade, daí a leveza de seu canto, a proximidade que ele guarda em relação à fala, a pequena presença de vibratos e outros tipos de ornamentação, a maneira de recortar ritmicamente as melodias seguindo o próprio texto das canções e a clareza na pronúncia. Aspectos que põem em primeiro plano o significado e as nuances da própria relação melodia/letra das composições. Ademais, prevalece o uso do registro modal (as ditas "voz de peito" e "voz de cabeça”, no jargão musical) e uma uniformidade em relação à qualidade vocal, "timbrística", presente no disco - as poucas variações ficam por conta principalmente da quantidade de ar emitida no canto. Contudo - e nesse ponto a performance ganha nova conotação, não mais restrita ao canto bossa-nova -, conforme o próprio material foge ao estilo bossa-novista propriamente dito, na medida em que o próprio conteúdo composicional tematiza questões que extrapolam os limites dessa estética e, por conseguinte, realiza-se formalmente de outra maneira, o gesto interpretativo de Nara passa a obedecer tais materialidades, flexionando-se, por meio de emissões e entoações mais densas e definidas, pode-se dizer, para além dos limites da gestualidade bossa-novista.

Assim, nessa nova abordagem musical, é verificável um lastro de continuidade estilística com a bossa nova, ainda que não se trate de um tipo de releitura de repertórios anteriores a ela, à maneira de João Gilberto e suas gravações de sambas de Geraldo Pereira, Ary Barroso e Dorival Caymmi, por exemplo. Em outro sentido, vislumbra-se aqui a abertura de novos caminhos interpretativos: de um lado, um movimento em direção a algumas tradições populares e a musicalidades anteriores aos sons das boates e apartamentos da zona sul efetuado, por outro lado, através de apropriações e releituras a partir de uma ótica ou um filtro bossa-novista. É a partir desse duplo movimento que um novo estilo "cancional" vai se desenvolvendo ao longo da década. Daí o avanço de uma nova estética, em que a "promessa de felicidade" 54 cede lugar à "necessidade de cantar".

\section{NARA: ESTÉTICA DO PRIMEIRO DISCO}

Como apontou Lorenzo Mammì, o long-play, mais que um mero suporte físico de obras musicais gravadas, foi também uma forma de expressão, uma forma artística no sentido pleno do termo - quase "como a sinfonia e o romance"55. No âmbito da música popular, para que o disco fosse alçado a tal condição, concorreram uma série de fatores e linguagens artísticas. A escolha refletida do repertório, das faixas que compõem um disco, permitiu a elaboração de trabalhos que representam verdadeiras

54 Ibidem.

55 Idem, A era do disco. Revista Piauí, edição 89, fevereiro de 20I4. 
"declarações de poética" 56 . Ademais, os conteúdos e formas das capas, dos encartes e textos de acompanhamento, bem como os aspectos visuais dos músicos e as estratégias de lançamento, passaram a ter cada vez mais relevância. Nas palavras de Mammì, "o disco já não era mais um som: era um mundo para o qual concorriam diferentes linguagens, um sistema de códigos, um modelo de vida”57.

Além de todos os aspectos musicais e performáticos já descritos, outros elementos merecem destaque numa apreciação do disco como um todo. Nesse sentido, a capa do LP é singular: uma foto em preto e branco da cantora, de autoria de Francisco Pereira, é processada em alto-contraste sobre um fundo totalmente branco e acompanhada pelo título do álbum, Nara. Num estilo simples e direto e ocupando boa parte do espaço da capa, a grafia do nome da cantora, na cor preta, possui contornos e padrões geométricos e certa simetria formal. Três pequenos círculos vermelhos são dispostos assimetricamente pela capa, acentuando o caráter geométrico e o estilo econômico na coloração.

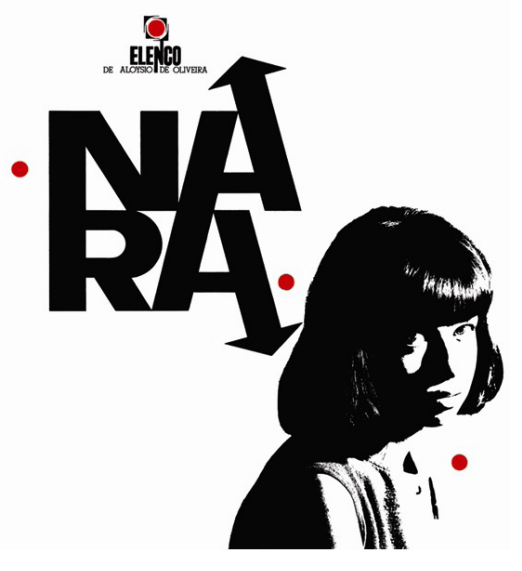

Figura 5-Capa do disco Nara

Essa estética visual, por assim dizer, foi uma das marcas dos discos da gravadora Elenco. O diretor de arte da empresa, Cesar Villela, foi o principal responsável por tais criações, que se tornaram padrão na época, sendo posteriormente copiadas por outras gravadoras. Ruy Castro atribui a realização desse tipo de capa à falta de recursos da própria gravadora ${ }^{58}$. De fato, a Elenco não possuía a mesma disponibilidade de recursos financeiros que as grandes gravadoras. Comandada por Aloysio de Oliveira, que exercia o papel de proprietário, diretor artístico, produtor, redator de contracapas e de material de divulgação, a gravadora marcou a história da música popular no Brasil. Em pouco mais de três anos de existência, Aloysio - músico e produtor de extensa carreira que durante alguns anos esteve integrado ao meio artístico

56 Mammì cita como exemplos, no âmbito da música popular, os discos Canções praieiras, de Dorival Caymmi,

Kind of blue e Sketches of Spain, de Miles Davis, e A love supreme, de John Coltrane. Ibidem.

57 Ibidem.

58 CASTRO, Ruy, op. cit., p. 340. 
bossa-novista - produziu cerca de 60 discos com os principais nomes desse fenômeno musical. Produções cujo foco teria sido a "qualidade artística", a espontaneidade e a sensibilidade dos músicos envolvidos, em detrimento de qualquer parâmetro puramente comercial ${ }^{59}$.

Voltando à capa do disco Nara, é possível apontar que seu estilo guarda alguma relação com o concretismo, com a arte e a poesia concretas, movimento que mudou os rumos da arte brasileira a partir dos anos $1950^{60}$. Estilisticamente, a disposição e o tamanho das letras, bem como seu formato, parecem aludir ao aspecto visual de vários poemas de Décio Pignatari e dos irmãos Campos (Haroldo e Augusto). Nesse sentido, a própria linguagem visual da capa concorre para a constituição de um sentido integrado do disco - visual e sonoramente. Intencionalmente ou não, as duas "setas" representadas na capa - como continuações de cada "A" da grafia do substantivo Nara -, apontando para direções opostas, aludem justamente àquele duplo movimento efetuado por Nara na seleção de seu repertório e em sua maneira de abordá-lo interpretativamente. Ou seja, um retorno a tradições populares por meio de um filtro bossa-novista; um movimento descendente em direção a musicalidades populares “pré-modernas", pré-bossa nova; e um movimento ascendente em que o estilo bossa-novista é expandido e incorpora novas temáticas e materiais.

Além dessa possível analogia, a própria alusão ao concretismo revela uma preocupação com critérios genéricos relativos a certa atualização artística da produção de música popular. Daí a referência visual a um movimento artístico moderno - concretismo - e, do mesmo modo, no plano musical, a manutenção daquelas "conquistas estéticas" da bossa nova, ainda que cada vez mais os conteúdos aludissem a tradições e sonoridades populares. Vale salientar que essa preocupação em atualizar formalmente a produção artística brasileira em relação aos grandes centros da Europa e aos Estados Unidos esteve na ordem do dia para toda uma geração de artistas. No campo da música dita erudita, por exemplo, um conjunto de compositores havia publicado, um ano antes, em São Paulo, o “Manifesto Música Nova”, cujos principais pontos eram justamente a atualização e a internacionalização da música produzida no Brasil ${ }^{65}$, em sintonia com "um compromisso total com o mundo contemporâneo"62 . Críticos do nacionalismo musical - uma vez que essa corrente foi hegemônica na produção erudita do país desde ao menos a década de 1930 - e defensores do "concretismo" - que simbolizaria "a atual etapa das artes"-, esses compositores defendiam uma arte "atualizada" e ao mesmo tempo

59 Ver: ZAN, Jose Roberto, op. cit., p. I2I-I28; e CASTRO, Ruy, op. cit., p. 339-343.

60 MAMMİ, Lorenzo. Entrevistado por Alvaro Machado. Concretismo paulista foi mais importante que semana de 22. Trópico, Dossiê Arte Concreta, São Paulo, 3 I de julho de 2002. Disponível em: <http://www.revistatropico. com.br/tropico/html/textos/I354,I.shl>. Acesso em: 6 mar. 2015.

6I CONTIER, Arnaldo Daraya. Música e ideologia no Brasil. São Paulo: Novas Metas, I985, p. 44-45.

62 COZZELLA, Damiano et al. Música Nova. Manifesto I963. Invenção - Revista de Arte de Vanguarda, ano 2, n. 3, junho I963. Disponível em: 〈http://www.latinoamerica-musica.net/historia/manifestos/3-po.html〉. Acesso em: 29 ago. 2015. 
participante, revolucionária ${ }^{63}$. A referência a Maiakovski na última frase do manifesto explicita a dupla intenção dos compositores: "sem forma revolucionária não há arte revolucionária" ${ }^{4}$. É justamente esse o sentido das escolhas efetuadas por muitos dos artistas envolvidos no engajamento político da produção dita popular. Pode-se dizer que boa parte dessa produção, mesmo quando voltada a uma arte de forte teor político, não abriu mão de aspectos formais que simbolizassem, ainda que genericamente, certa "sofisticação" e "modernidade".

\section{CONSIDERAÇÕES FINAIS}

Como se viu, Nara Leão fez parte daquele meio artístico que se formou em torno das primeiras experiências bossa-novistas. A cantora marcou presença em pequenos shows, e sua casa foi um dos famosos redutos das reuniões da "turma" da bossa nova. Tal convívio motivou, nos primeiros anos da década de I960, o rótulo de "musa da bossa nova" endereçado à cantora. Em I962, chegou a se apresentar com João Gilberto, em São Paulo, antes de iniciar suas primeiras gravações, como aquelas realizadas a convite de Carlos Lyra, em I963. Contudo, até essa data, a atuação da referida "musa" além de inspirar o letrista e namorado Ronaldo Bôscoli ${ }^{65}$, segundo o próprio - parecia restringir-se a essas pequenas apresentações - muitas das quais "semiamadoras" - e ao papel de anfitriã nas reuniões de seus colegas já profissionais. Mesmo a intérprete parecia não compreender a razão de tamanha reverência:

[A musa da bossa nova] já existia nos jornais. O que, aliás, para mim é um mistério. Na verdade, o pessoal da bossa nova me escorraçava um pouco. Então até hoje eu não entendi como que eu era a musa e todo mundo me espinafrava [...]. Deve ter sido o jornal. O Ronaldo [Bôscoli] era outro que achava que eu desafinava, que eu cantava mal, que não dava pé. Vivia me pichando, era um horror. Então não era tão musa assim. Eu tenho a impressão de que os jornais talvez vissem assim, uma menininha no meio daquele pessoal todo, os marmanjos e as pessoas mais velhas. Eu era uma garota, era uma coisa simpática, meio mascote. Mas musa mesmo, eu acho que infelizmente não fui ${ }^{66}$.

Daí a dificuldade da própria cantora em compreender o porquê do rótulo de musa da bossa nova. Como ela seria musa se pouco cantava e se poucos aprovavam sua atuação?

A partir do ano de I962, Nara passa a trilhar outros caminhos em sua trajetória. A partir de um maior contato com artistas como Ruy Guerra, Cacá Diegues e Carlos Lyra, a cantora se aproxima de um novo universo de questões artísticas e políticas. As primeiras produções de Nara nesse âmbito ocorrem no ano de I963. No mês de março, estreia, na boate Au Bon Gourmet, o show Trailer, um prólogo do espetáculo

\footnotetext{
63 Ibidem.

64 Ibidem.

65 BÔSCOLI, Ronaldo, op. cit., I994.

66 LEÃO, Nara, 20I4, op. cit., p. 33-34.
} 
Pobre menina rica, composto por Lyra e Vinícius de Moraes. Em agosto, a cantora inicia a gravação de seu primeiro disco.

Em depoimento ao MIS, no Rio de Janeiro, a intérprete comenta sobre as motivações e possíveis causas de sua mudança artística e política e o quanto isso significou para sua carreira.

Eu acho que tomei conhecimento da música do morro através do Carlinhos Lyra, que morava ali na Barão da Torre e era amigo do Zé Kéti e do Cartola. Eu conheci na mesma época o pessoal do cinema, Cacá Diegues, Paulo Cesar Saraceni, Ruy Guerra, e eles estavam fazendo 5 vezes favela. Nessa época, eu achei que eu ia ser montadora de cinema, fui aprender montagem, e tive uma certa convivência com essa realidade. Não foi através do morro mesmo não, foi através do cinema, muito indiretamente. Através do 5 vezes favela, as músicas do Zé Kéti, o teatro do Vianninha, todo aquele movimento me impressionou muito, tomar conhecimento de uma realidade social que eu não conhecia, que eu absolutamente nunca tinha ouvido falar. Eu era uma menina muito angustiada, desde a infância, era meio problemática, meio baixo astral, e quando eu descobri essas coisas, pensei que talvez pudesse prestar um serviço, pudesse fazer da minha vida uma vida útil e fazer uma coisa pelos outros. Afinal, eu estava na fossa, mas meu problema era muito pequeno, tem gente aí com problemas reais, aí eu dei uma virada ${ }^{67}$.

Esse distanciamento em relação à bossa nova foi movido principalmente por uma crescente preocupação política partilhada por toda uma geração de artistas. A dita moderna música popular, a partir dessa nova clivagem, teria funções políticas, teria capacidade de conscientizar os ouvintes sobre as mazelas sociais do país. Os artistas engajados, identificados com certo ideário nacional-popular vigente, deveriam buscar nas "raízes populares" a vitalidade e a autenticidade capazes de nutrir, estética e politicamente, suas produções. A necessidade de falar sobre o Brasil, de "conscientizar" os ouvintes, de agir politicamente, pautou boa parte da produção artística e musical desses anos.

Nesse sentido, a trajetória de Nara Leão se assemelha ao direcionamento artístico de nomes como Carlos Lyra, Sérgio Ricardo, Vinícius de Moraes, Geraldo Vandré, entre outros. Pode-se dizer que nesse momento suas produções passam a apresentar um reprocessamento das conquistas estéticas da bossa nova que, de maneira gradativa, vão sendo articuladas a certos parâmetros advindos de tradições populares, como o dito "samba de morro" e variadas musicalidades regionais (principalmente aquelas que remetiam ao sertão nordestino). Do mesmo modo, as mensagens de conotação social e política vão se tornando uma constante nessa produção.

A apreciação comentada do primeiro disco da cantora e a descrição dos anos iniciais de sua trajetória foram aqui utilizadas com o objetivo de evidenciar de que maneira sua atuação artística e sua performance, ou mesmo, num recorte mais amplo, sua "personalidade musical”, refletem essa guinada estética em relação à bossa nova. Guinada essa que corresponde mesmo a um novo direcionamento não só da trajetória

67 Ibidem, p. 34-35. 
individual da cantora como de toda uma geração de artistas que almejava retratar, por meio da arte, questões mais amplas do plano cultural e político.

Por fim, é possível apontar que a tomada de posição da intérprete não consiste em um rompimento definitivo com a bossa nova, uma vez que seu estilo interpretativo manteve-se em sintonia com as "inovações" bossa-novistas. Ademais, como se viu, Nara esteve profissionalmente pouco integrada a esse meio, desempenhando aí papel secundário. E, apesar de ter se "formado" musicalmente dentro desse âmbito, seus pares conservavam baixa estima em relação a suas capacidades artísticas - ainda que pudessem apreciar a hospitalidade e a disponibilidade em ceder o apartamento de seus pais para abrigar inúmeras reuniões musicais. Daí, quando da profissionalização da cantora, pode-se dizer que não teria ocorrido um rompimento efetivo com tal estilo musical ${ }^{68}$, mas sim uma guinada e uma busca de um caminho próprio. Distanciamento da bossa nova que, não obstante, teve como parâmetro suas conquistas estéticas, na medida em que outros repertórios eram relidos e incorporados à sua produção através de um "filtro" bossa-novista. Essa "virada" estética (e política) pode ser efetivamente observada em sua performance musical registrada em seu primeiro LP.

Em Nara, o gesto interpretativo mobilizado pela cantora guarda ainda forte ligação com a bossa nova, berço de sua musicalidade. Daí a leveza de seu canto, a proximidade que ele guarda em relação à fala, entre outros aspectos acima discutidos. Entretanto, na medida em que tal repertório representa uma abertura da bossa nova em direção a outras musicalidades, abordando novos temas e incorporando novos elementos e procedimentos musicais, a realização do canto já não se dá como num disco de bossa nova típico, uma vez que o próprio material musical passa a exigir da intérprete uma nova gestualidade.

\section{SOBRE O AUTOR}

ISMAEL DE OLIVEIRA GEROLAMO é doutorando em Música pela Universidade Estadual de Campinas (Unicamp).

E-mail: ismael.gerolamo@gmail.com

68 É sabido que no ano de 1964 uma série de declarações de Nara Leão contribuiu para instaurar uma querela significativa entre os bossa-novistas “de primeira hora” e os músicos identificados com a canção engajada. Donde um possível rompimento, ao menos no plano político, com a bossa nova. 


\section{REFERÊNCIAS BIBLIOGRÁFICAS}

ALVIM, Thereza Cesario. A bossa como ela é. Última hora, Rio de Janeiro, Io de abril de I963. Caderno 2. AMARAL, Ricardo. Ricardo Amaral (Coluna). Última hora, Rio de Janeiro, 30 de junho de I96I. Caderno 2, p. I4.

BÔSCOLI, Ronaldo. Eles e eu: memórias de Ronaldo Bôscoli. Depoimento a L. C. Maciel e A. Chaves. Rio de Janeiro: Nova Fronteira, I994.

“BOSSA NOVA” foi à faculdade: ganhou nota Io!. Última Hora, Rio de Janeiro, 23 de maio de I960. Caderno 2, p. то.

BRITO, Brasil Rocha. Bossa Nova. In: CAMPOS, Augusto de. Balanço da bossa e outras bossas. 4. ed. São Paulo: Perspectiva, I986.

CABRAL, Sérgio. Nara Leão: uma biografia. Rio de Janeiro: Lumiar, 200I.

CAMPOS, Augusto de. Balanço da bossa e outras bossas. 4. ed. São Paulo: Perspectiva, I986.

CASTRO, Ruy. Chega de saudade: a história e as histórias da bossa nova. São Paulo: Companhia das Letras, I990.

CONTIER, Arnaldo Daraya. Música e ideologia no Brasil. São Paulo: Novas Metas, I985.

COZZELLA, Damiano et al. Música Nova. Manifesto I963. Invenção - Revista de Arte de Vanguarda, ano 2, n. 3, junho I963. Disponível em: <http://www.latinoamerica-musica.net/historia/manifestos/3-po. html $>$. Acesso em: 29 ago. 2015 .

ELIAS, Norbert. Mozart: sociologia de um gênio. Rio de Janeiro: Jorge Zahar, I994.

GARCIA, Walter. Bim Bom: a contradição sem conflitos de João Gilberto. São Paulo: Paz e Terra, I999.

GRIDLEY, Mark C. Jazz styles: history and analysis. 7. ed. New Jersey: Prentice Hall, I999.

GUINZBURG, Carlo. O queijo e os vermes. São Paulo: Cia. das letras, 2006.

INSTALA-SE clube para defender "bossa nova". Última Hora, Rio de Janeiro, I4 de setembro de I96o. Caderno 2, p. 2.

LEÃO, Nara. Nara. Rio de Janeiro: Elenco, I964. I disco sonoro. . Depoimento. Museu da Imagem e do Som (MIS). Rio de Janeiro, 6 de julho de I977. Depoimento de Nara Leão a João Vicente Salgueiro, Roberto Menescal e Sérgio Cabral. In: GOMES, A. A. de A. (Org.). Nara Leão - Encontros. Rio de Janeiro: Azougue Editorial, 20I4.

LEVI, Giovanni. Sobre a micro-história. In: BURKE, P. (Org.). A escrita da história: novas perspectivas. São Paulo: Editora da Unesp, I992.

LINS E BARROS, Nelson. Texto da contracapa do disco Depois do carnaval.... In: LYRA, Carlos. Depois do carnaval..., Philips, I963. I disco sonoro.

LYRA, Carlos. Depois do carnaval... Philips, I963. I disco sonoro.

MACHADO, Ney. Festival da bossa nova no Bon Gourmet. Diário de notícias, Rio de Janeiro, 20 de dezembro de I962, segunda seção, p. 4 .

MAMMİ, Lorenzo. João Gilberto e o Projeto Utópico da Bossa Nova. Revista Novos Estudos Cebrap, São Paulo, n. 34, I992.

Concretismo paulista foi mais importante que Semana de 22. Trópico, Dossiê Arte Concreta, São Paulo, 3I de julho de 2002. Entrevistado por Alvaro Machado. Disponível em <http://www.revistatropico.com.br/tropico/html/textos/I354,I.shl>. Acesso em: 6 mar. 2015.

. A era do disco. Revista Piauí, edição 89, fevereiro de 2014.

MEDAGLIA, Julio. Balanço da bossa. In: CAMPOS, Augusto de. Balanço da bossa e outras bossas. 4. ed. São Paulo: Perspectiva, I986. 
MULLER, Maneco. Jacinto de Thormes (Coluna). Última hora, Rio de Janeiro, 30 de março de I963. Caderno 2.

NAPOLITANO, Marcos. Seguindo a canção: engajamento político e indústria cultural na MPB (I959-I969). São Paulo: Annablume/Fapesp, 200I, p. I36.

. A síncope das ideias. São Paulo: Fundação Perseu Abramo, 2007.

NARA LEÃO. Site oficial. Cronologia. Disponível em: <http://www.naraleao.com.br/index.php?p=cronologia $>$. Acesso em: 27 maio 2015.

NAVES, Santuza. Canção popular no Brasil. Rio de Janeiro: Civilização Brasileira, 2010.

OLIVEIRA, Aloysio. Texto da contracapa do disco Nara. In: LEÃO, Nara. Nara. Rio de Janeiro: Elenco, I964. I disco sonoro.

PAIVA, Maurício de. Maurício de Paiva (Coluna). Última hora, Rio de Janeiro, 29 de março de I963. Caderno 2.

SANT'ANNA, Afonso Romano de. Música popular e moderna poesia brasileira. Rio de Janeiro: Vozes, I986.

SANTOS, Fábio Saito dos. "Estamos aí”: um estudo das influências do jazz na bossa nova. Dissertação (Mestrado em Música). Instituto de Artes, Universidade Estadual de Campinas, 2006.

SARAIVA, Joana Martins. A invenção do sambajazz: discursos sobre a cena musical de Copacabana no final dos anos de 1950 e início dos anos I960. Dissertação (Mestrado em História). Programa de PósGraduação em História Social da Cultura, Pontifícia Universidade Católica do Rio de Janeiro, 2007.

SOUZA, Miliandre Garcia. Do teatro militante à música engajada: a experiência do CPC da UNE (I958-I964). São Paulo: Fundação Perseu Abramo, 2007.

TATIT, Luiz; LOPES, Ivã Carlos. Elos de melodia e letra: análise semiótica de seis canções. Cotia: Ateliê Editorial, 2008.

THORMES, Jacinto de. Sociedade e adjacências. Última hora, Rio de Janeiro, 30 de março de I963. Caderno 2.

ZAN, Jose Roberto. Do fundo de quintal à vanguarda: contribuição para uma história social da música popular brasileira. Tese (Doutorado em Sociologia). Instituto de Filosofia e Ciências Humanas, Universidade Estadual de Campinas, I997. 